\title{
Pediatric Multiple Sclerosis Before the PARADIGMS Study: Nine Years of Experience in a Portuguese Tertiary Center
}

\section{Esclerose Múltipla Pediátrica Antes do Estudo PARADIGMS: Nove Anos de Experiência num Centro Terciário Português}

Catarina Fernandes ${ }^{1}$, (D) João Durães ${ }^{2,3}$, (D) Filipa Rodrigues ${ }^{2}$, (D) Joana Afonso Ribeiro ${ }^{2}$, (D) Inês Correia ${ }^{3}$, (D) Maria do Carmo Macário ${ }^{3}$, Carla Cecília Nunes ${ }^{3}$, (D) Sónia Batista ${ }^{3}$, Carmen Costa ${ }^{2}$, Cristina Pereira ${ }^{2}$, Conceição Robalo ${ }^{2}$, Isabel Fineza 2, (D) Lívia Sousa ${ }^{3}$, Mónica Vasconcelos ${ }^{2}$, (D) Filipe Palavra 2,4,5,*

1-Faculty of Medicine, University of Coimbra, Coimbra, Portugal

2-Center for Child Development - Neuropediatrics Unit, Hospital Pediátrico, Centro Hospitalar e Universitário de Coimbra, Coimbra, Portugal

3-Neurology Department, Centro Hospitalar e Universitário de Coimbra, Coimbra, Portugal

4-University of Coimbra, Institute for Clinical and Biomedical Research (iCBR), Faculty of Medicine, Coimbra, Portugal

5-Clinical Academic Center of Coimbra (CACC), Coimbra, Portugal

DOI: https://doi.org/10.46531/sinapse/AO/200062/2021

\section{Abstract}

Background: Multiple sclerosis (MS) is an inflammatory and demyelinating disease of the central nervous system that may have a pediatric onset. This study aims to provide a characterization of a pediatric-onset MS (POMS) population followed at our center in the 9-year period prior to the PARADIGMS study, which resulted in the first formal approval of a drug to treat POMS.

Material and Methods: We performed a retrospective, observational and unicentric study. We included data from the records of patients with an MS diagnosis confirmed before the age of 18, according to the McDonald 2010 diagnostic criteria, from 1st January 2010 onwards.

Results: In a group of 32 patients, 30 (73.3\% female) fulfilled the inclusion criteria, with a mean age at diagnosis of $15.5 \pm 2.2$ years and median value of Expanded Disability Status Scale (EDSS) score at diagnosis of 1.5. All the cases had relapsing-remitting MS and in 43.3\% optic nerve involvement was the first clinical manifestation. At diagnosis, magnetic resonance imaging showed gadolinium-enhancing lesions in $50 \%$ of the cases and the study of cerebrospinal fluid revealed oligoclonal bands in $85.7 \%$. Interferon beta-1a was the most frequent first treatment option. In a mean follow-up of $4.1 \pm 2.5$ years, the treatment was changed in $67.9 \%$ of cases. On the last visit, the median EDSS score was 1.5.

Conclusion: Our results are in line with contemporaneous research. As well as contributing an important descriptive analysis of this population's characteristics, it also provides a window of opportunity for further prospective analyses regarding potential treatment paradigm changes.

\section{Resumo}

Introdução: A esclerose múltipla (EM) é uma doença inflamatória e desmielinizante do sistema nervoso central que pode ter início em idade pediátrica. Este estudo tem como objetivo a caracterização de uma população de doentes com EM de início em idade pediátrica (POMS) acompanhada no nosso centro no período de 9 anos, antes da publicação do estudo PARADIGMS, de que resultou a aprovação formal de um primeiro fármaco para tratamento da POMS.

Material e Métodos: Estudo retrospectivo, observacional e unicêntrico, incluindo dados das crianças e adolescentes com diagnóstico de EM confirmado antes dos 18 anos de idade, a partir da data de 1 de Janeiro de 2010, de acordo com os critérios de McDonald 2010.
Informações/Informations: Artigo Original, publicado em Sinapse, Volume 21, Número 1, janeiro-março 2021. Versão eletrónica em www.sinapse.pt Original Article, published in Sinapse, Volume 21, Number 1 january-march 2021. Electronic version in www.sinapse.pt (C) Autor (es) (ou seu (s) empregador (es)) e Sinapse 2021. Reutilização permitida de acordo com CC BY-

NC. Nenhuma reutilização comercial.

(C) Author(s) (or their employer(s)) and Sinapse 2021 Re-use permitted under CC BYNC. No commercial re-use.

\section{Keywords: \\ Child \\ Fingolimod; \\ Multiple Sclerosis/diagnosis \\ Multiple Sclerosis/drug \\ therapy.}

Palavras-chave:

Criança;

Esclerose Múltipla/diagnóstico Esclerose Múltipla/tratamento farmacológico:

Fingolimod.

\section{*Autor Correspondente / Corresponding Author: Filipe Palavra \\ Centro de Desenvolvimento da \\ Criança - Neuropediatria \\ Hospital Pediátrico \\ Centro Hospitalar e \\ Universitário de Coimbra 3000-602 Coimbra, Portugal fpalavra@fmed.uc.pt}

Recebido / Received: 2020-11-05 Aceite / Accepted: 2021-02-16 Publicado / Published: 2021-04-16 
Resultados: Identificaram-se 32 pacientes, dos quais 30 ( $73,3 \%$ do género feminino) preencheram os critérios de inclusão, com idade média ao diagnóstico de 15.5 \pm 2.2 anos e valor mediano na pontuação da Escala de Incapacidade Expandida (EDSS) de 1,5. Todos os casos eram formas surto-remissão. Em 43,3\% deles, o envolvimento do nervo óptico foi a primeira manifestação clínica. Ao diagnóstico, a ressonância magnética mostrou lesões com realce após administração de gadolínio em $50 \%$ dos casos e o estudo do líquido cefalorraquidiano revelou bandas oligoclonais em $85,7 \%$. O interferão beta-1a foi a primeira opção de tratamento mais frequentemente usada. Após uma média de seguimento de 4,1 $\pm 2,5$ anos, o tratamento foi alterado em $67.9 \%$ dos casos. Na última consulta efetuada, a pontuação mediana na EDSS foi de 1,5.

Conclusão: Os nossos resultados estão em linha com o que se encontra publicado. Para além de uma análise descritiva das características desta população, este estudo permite uma abordagem prospectiva adicional, que verse sobre potenciais mudanças no paradigma de tratamento destas crianças e adolescentes.

\section{Introduction}

Pediatric-onset multiple sclerosis (POMS) has been increasingly recognized as having some distinctive features from adult-onset multiple sclerosis (MS), with a more inflammatory component and higher relapse rates, but slower progression. ${ }^{1-5}$

Diagnosis in childhood is currently based on the International Pediatric Multiple Sclerosis Study Group (IPMSSG) criteria, ${ }^{6}$ which incorporate the McDonald criteria, ${ }^{7}$ but can be challenging due to several clinical entities having similar findings. The 2017 revised McDonald criteria ${ }^{7}$ have proven to be equally applicable to POMS and MS in adults, providing a simplified means to reach the diagnosis at onset and over time., ${ }^{8,9}$

While the classic first-line treatment for pediatric MS has been interferon-beta or glatiramer acetate, ${ }^{10}$ more recent drugs, namely natalizumab, dimethylfumarate and fingolimod, are often used in pediatric MS with similar short-term safety, tolerability, and side effect profiles to adults. ${ }^{10}$ In fact, with the publication of the PARADIGMS study (Trial of Fingolimod versus Interferon Beta-la in Pediatric Multiple Sclerosis), fingolimod became the first drug to be used in the treatment of POMS with the formal approval of the regulatory authorities." This brought a confident change in the therapeutic approach to this condition in children and adolescents, and gave an incentive to better define its pathophysiology, particularly in this age group. Clinicians will now be able to compare the pre-approval and post-approval phases, in order to measure and reflect on their therapeutic choices.

With this study, we aimed to perform a biodemographical and clinical characterization of patients with POMS followed at a pediatric reference center in our country, in order to evaluate the approach used with these patients before the existence of any formal approval for the pharmacological therapy of this condition.

\section{Material and Methods}

We performed a cross-sectional unicentric study, including patients with a confirmed diagnosis of MS established at pediatric age (under 18 years old), according to the 2012 IPMSSG $^{6}$ and 2010 McDonald criteria, ${ }^{12}$ followed at the Centro Hospitalar e Universitário de Coimbra in the period between January 2010 and December 2018. We excluded patients without subsequent follow-up or in which an alternative diagnosis was established.

This study was approved by the National Commission for Data Protection and by the Ethics Committee of our institution. It followed the principles of the Declaration of Helsinki 2013, national legislation for clinical research and good clinical practice norms (ICH-GCP).

\section{Procedures}

We collected data from patients' clinical records, including:

I) Biodemographical characteristics: birth date, gender, educational level, current body mass index, age at menarche (for female patients), family history of MS and practice of physical exercise (current, at the time of the last appointment and/or in the past, i.e. any physical exercise previous to the last appointment);

2) Clinical data: age at first clinical manifestation and at MS diagnosis, first clinical manifestation, pheno- 
type classification of disease, Expanded Disability Status Scale (EDSS) score at diagnosis and in the last consultation, past medical and surgical history, current and past disease-modifying drugs (DMDs) (drug, duration of the treatment and reason for discontinuation), other current treatments, number of relapses and treatment of relapses;

3) Complementary exam results: first magnetic resonance imaging (MRI), presence of anti-myelin oligodendrocyte glycoprotein (anti-MOG) or antiaquaporin 4 (anti-AQP4) antibodies, visual evoked potentials, presence of oligoclonal bands in the cerebrospinal fluid (by isoelectric focusing) and presence of antibodies against cytomegalovirus (CMV) and Epstein-Barr virus (EBV).

We defined physical exercise as any body movement generated by the contraction of skeletal muscles that raises energy expenditure above the resting metabolic rate and which is planned, structured, and repetitive (more than three times per week).

A relapse was defined as the existence of new neurological symptoms or signs lasting for more than 24 hours, in the absence of concurrent disease. Different relapses were defined by having an interval of time greater than 30 days between them. Therapeutic ineffectiveness was defined as follows: occurrence of two relapses in one year under therapy; or identification of at least 5 new T2 lesions on consecutive MRls performed under therapy; or identification of 2 new gadolinium-enhancing lesions also on consecutive MRIs under therapy. By protocol, this MRI evaluation is performed on an annual basis. The same team of neuroradiologists was responsible for the analysis of all images.

\section{Statistical analysis}

We performed a descriptive analysis of clinical and biodemographical characteristics. Qualitative variables were displayed as absolute value and percentage, and quantitative variables as minimum and maximum mean \pm standard deviation.

The normality of the variables was assessed using the Kolmogorov-Smirnov test for physical exercise in childhood, current physical exercise and number of relapses, and the Shapiro-Wilk test for age at menarche, age at diagnosis and number of relapses in female patients. A Mann-Whitney $U$ test was performed to evaluate the correlation between the number of relapses and current or past physical exercise. The analysis of a possible correlation between age at menarche and age at diagnosis was assessed by the Spearman coefficient. All analyses were performed with IBM SPSS ${ }^{\circledR}$ statistics 25 software.

\section{Results}

We identified 32 patients, from which 2 were excluded due to the absence of subsequent follow-up. Our sample $(n=30)$ had a mean diagnosis age of $15.4 \pm 2.2$ years and the time between the first clinical manifestation and diagnosis was $0.4 \pm 0.7$ years (Table 1). The female:male ratio was $2.75: 1$. A positive family history for MS was present in 6 patients (20.0\%). Mean followup time was $4.1 \pm 2.5$ years and I patient died during follow-up from causes unrelated to MS (car accident).

Table 1. Biodemographical characteristics and initial diagnostic workup.

\begin{tabular}{|l|r|r|}
\hline & N (\%) & Mean \pm SD \\
\hline \multicolumn{2}{|l|}{ Biodemographical characteristics } \\
\hline Age at diagnosis & $30(100 \%)$ & $15.4 \pm 2.2$ years \\
\hline $\begin{array}{l}\text { Age at first clinical } \\
\text { manifestation }\end{array}$ & $30(100 \%)$ & $15.0 \pm 2.4$ years \\
\hline Female gender & $22(73.3 \%)$ & \\
\hline Age at menarche & $21(70.0 \%)$ & $12.7 \pm 1.4$ years \\
\hline BMl at last visit & $27(90.0 \%)$ & $21.0 \pm 2.5 \mathrm{~kg} / \mathrm{m}^{2}$ \\
\hline Family history of MS & $6(20.0 \%)$ & \\
\hline Past physical exercise & $9(30.0 \%)$ & \\
\hline Current physical exercise & $6(20.0 \%)$ & \\
\hline Initial diagnostic workup & & \\
\hline Brain MRI & $30(100 \%)$ & \\
\hline Spinal cord MRI & $14(46.7 \%)$ & \\
\hline $\begin{array}{l}\text { DIS and DIT criteria on } \\
\text { first MRI }\end{array}$ & $18(60.0 \%)$ & \\
\hline Lumbar puncture & $21(70.0 \%)$ & \\
\hline Oligoclonal bands & $18(85.7 \%)$ & \\
\hline
\end{tabular}

$\mathrm{N}$ : number of patients; SD: standard deviation; BMI: body mass index; MRI: magnetic resonance imaging; DIS: dissemination in space; DIT: dissemination in time.

During the initial diagnostic workup, all patients $(n=30)$ underwent brain MRI and I4 were also submitted to spinal cord imaging (Table 1). Dissemination in space (DIS) and dissemination in time (DIT) criteria were found in $18(60.0 \%)$ and DIS criteria in $9(30.0 \%)$ of the patients. Oligoclonal bands were present in 18 
(85.7\%) of those who had a lumbar puncture (performed in 21 patients).

The application of the 2017 McDonald criteria to our cohort would have allowed us to make a POMS diagnosis in I patient who presented a first demyelinating event that, at the time, was only considered to be a clinically isolated syndrome. Nevertheless, that patient developed a second relapse months later, resulting in a diagnosis of clinically definite POMS.

Regarding the seasonal distribution of the patients' birth, II (36.6\%) were born in the autumn months (September, October and November), 8 (26.7\%) in the winter (December, January and February), 8 (26.7\%) in the spring (March, April and May) and 3 (10.0\%) in the summer (June, July, August).

In our cohort, $10.0 \%$ of the patients attended elementary school, $33.3 \%$ went to high school, $16.7 \%$ did a technical or professional course, $33.3 \%$ got a university degree and data on $6.7 \%$ remain unknown. However, 26 patients did not finish their studies yet.

Regarding their past medical history, more than $25.0 \%$ of patients were diagnosed with another immune-mediated condition: atopic dermatitis (13.3\%), asthma (3.3\%), chronic sinusitis (3.3\%) and both asthma and allergic rhinitis (6.7\%).

Involvement of the optic nerve or spinal cord were the most common first clinical manifestations, occurring in 13 and 12 of the patients, respectively. Another 4 patients had brainstem relapses and I patient had a cortical presentation, consisting of a focal seizure, presenting with right head deviation and left upper limb tonic posture.
During follow-up, serologic tests were performed for EBV $(n=I I)$ and CMV $(n=I 2)$. Immunity was confirmed for EBV in 10 cases (90.9\%) and for CMV in 5 (4I.7\%). Anti-MOG and anti-AQP4 antibodies were studied in two patients, with negative results. Visual evoked potentials were performed in two patients, both with optic neuritis at presentation, revealing an increase of latency for PI 00 wave in I patient and a normal result in the other.

A DMD was initiated in 28 patients (93.3\%) (Table 2). Two patients did not start taking a DMD: in one case it was a personal/family decision and in the other it was due to a medical team decision. The first choice in the majority of cases was first-line injectable drugs (60.0\%). Two patients from our sample were included in a clinical trial, so their treatment remains unknown. DMD treatment was changed in 19 patients $(67.9 \%)$ during follow-up (the change occurred after 16 months, on average). One patient was treated with cyclophosphamide $800 \mathrm{mg} / \mathrm{m}^{2}$ for 12 months as an induction treatment, followed by interferon beta- $\mathrm{l}$. The most common reason for treatment discontinuation was ineffectiveness and the majority of side effects documented were related to skin reactions to the injection of subcutaneous drugs. Only I patient complained of abdominal pain with dimethylfumarate. This information is summarized in Table 2, which also contains DMDs currently in use.

The mean follow-up time was $4.1 \pm 2.5$ years and the mean number of relapses during follow-up was $2.2 \pm 1.4$. The majority of the relapses involved the spinal cord (40\%) or the optic nerve (32.3\%). Additionally, I8.5\% of them involved the brainstem, $7.7 \%$ simultaneously

Table 2. Use of DMDs during follow-up.

\begin{tabular}{|l|r|r|r|r|}
\hline DMD & $\begin{array}{r}\text { Number of patients as } \\
\text { first DMD } \\
\mathbf{n}(\%)\end{array}$ & $\begin{array}{r}\text { Number of patients as } \\
\text { current DMD } \\
\mathbf{n}(\%)\end{array}$ & $\begin{array}{r}\text { Mean duration } \\
\text { of use } \\
\mathbf{m}(\mathbf{S D})\end{array}$ & $\begin{array}{r}\text { Reason for } \\
\text { discontinuation } \\
\mathbf{n}\end{array}$ \\
\hline Interferon beta-1a & $9(30.0 \%)$ & $7(24.1 \%)$ & $30.2(17.7)$ & $\begin{array}{r}\text { Ineffectiveness 3 } \\
\text { Personal choice 2 }\end{array}$ \\
\hline Interferon beta-1b & $2(6.7 \%)$ & - & $24.7(14.3)$ & Ineffectiveness 2 \\
\hline Glatiramer acetate & $7(23.3 \%)$ & - & $18.6(11.4)$ & $\begin{array}{r}\text { Ineffectiveness } 5 \\
\text { Side effects 3 }\end{array}$ \\
\hline Dimethylfumarate & - & $7(14.1 \%)$ & 9.0 & Side effects 1 \\
\hline Natalizumab & $6(20.0 \%)$ & $6(20.7 \%)$ & $27.0(23.0)$ & $\begin{array}{r}\text { Ineffectiveness 2 } \\
\text { Personal choice 2 }\end{array}$ \\
\hline Fingolimod & $1(3.3 \%)$ & $5(17.2 \%)$ & 1.0 & Ineffectiveness 1 \\
\hline Cyclophosphamide & $1(3.3 \%)$ & - & 12.0 & Safety 1 \\
\hline
\end{tabular}

DMD: disease-modifying drug; n: number of patients; m: months; SD: standard deviation. 
affected the optic nerve and the brainstem and 1.5\% were exclusively attributed to a cortical topography.

The treatment choice for relapses was mainly intravenous methylprednisolone (78.5\%), with a typical regimen of 500-1000 mg once daily for 3-5 days. Intravenous immunoglobulin and plasmapheresis were used in I case (I.5\%). In I 3 relapses (20.0\%) no treatment was needed.

The median EDSS score at the last visit was 1.5 (minimum: 0; maximum: 3 ), as it was at the time of diagnosis (minimum: I; maximum: 3.5 ).

Current physical exercise practice was reported in 6 patients (20.0\%) and past physical exercise in 9 (30.0\%). However, no correlations were found between past or current physical exercise and the number of relapses in our sample. The mean age at menarche in our cohort was I 2.7 years. No correlations were found between age at menarche and age at diagnosis in female patients $(p>0.05)$.

\section{Discussion}

We described a cohort of patients with POMS, focusing on relevant clinical aspects, in order to better understand clinical practice at our center, particularly in terms of therapeutic intervention, before the existence of any formal approval for a drug at pediatric age. The mean age at diagnosis and female predominance were in accordance with previous studies, particularly reflecting the reality of the pediatric population in Portugal. ${ }^{5}$ Our patients had a higher prevalence of a positive family history for MS (20.0\% vs $6 \%-13.5 \%$ in international studies and $2 \%$ in another Portuguese study), ${ }^{5}$ which may reflect regional differences yet to be explored (our center is the reference hospital for the whole central region of Portugal, with a population of 2216569 million, according to the latest data published by the National Statistical Institute). ${ }^{13}$

Portugal is a sunny country and the analysis of a very young population was an opportunity to explore the possible relationship between the month of birth, as an indirect variable related to neonatal vitamin $D$ levels, and the later diagnosis of POMS. Vitamin D deficiency has been associated with more susceptibility to MS, including in pediatric patients, although the reasons are still not fully understood. ${ }^{14,15}$ Interestingly, approximately two thirds of our patients were born in the autumn or winter months, during which the number of hours of sunshine per day is reduced, further supporting the hypothetical role for seasonal changes in MS susceptibility. ${ }^{16}$ Even so, it is important to note that all children are supplemented with vitamin $D$ in the first year of life, in Portugal, as recommended by the national child health program.

The mean age at menarche in our cohort was similar to the general Caucasian population in the United States of America and did not correlate with age at diagnosis, not supporting, at least in our cohort, a role for hormonal factors in the early onset of the disease. ${ }^{17}$ Serology for EBV, a pathogen often considered a risk factor for MS, was positive in $90.9 \%$ of the patients tested, which is in line with what is known about the epidemiology of this viral infection and its possible contribution to immune-mediated diseases such as MS. ${ }^{18}$ However, serology for CMV was positive in only $41.7 \%$ of the patients tested, confirming other studies that there is no positive association between this pathogen and MS. ${ }^{19}$

In our cohort, $20.0 \%$ of the patients reported the current practice of physical exercise, and its benefits in MS are well established. ${ }^{20}$ This is an interesting topic for future research, since the pediatric population usually presents high levels of physical activity, in order to understand to what extent exercise can modulate the course of the disease. We did not observe relevant differences in the characteristics of the disease when comparing children with high levels of physical activity to those with lower levels in our population. However, the follow-up time was relatively short and longer observation periods would be necessary to infer whether or not physical exercise had any immunomodulating effect in addition to the DMDs. Associated immune-mediated diseases affecting the respiratory system were very frequent in our cohort, confirming the fact that there is an aggregation of these diseases in susceptible individuals, requiring assertive and regular medical control. We did not find any specific environmental explanation for the predominance of diseases affecting the respiratory system in our population.

The first clinical manifestation involved the optic nerve in $43.3 \%$ of the cases and the spinal cord in $40.0 \%$, which is in agreement with previous reports. ${ }^{9}$ An initial MRI study of the brain and spinal cord supported the diagnosis, with DIS and DIT criteria in $60.0 \%$ of the cases, leading to an early diagnosis shortly after the first clinical manifestation appeared. Oligoclonal bands were also an important part of the diagnostic workup and were present in the majority of cases (85.7\%), although in lower numbers than was reported in adult-onset 
MS (98\%). ${ }^{5}$ It is important to mention that in the last few years we have been working on raising awareness of POMS in the pediatric departments of smaller hospitals in our region in order to achieve the early diagnosis of the disease and recognition of the clinical manifestations that may correspond to first relapses. In fact, we have observed a much earlier referral of these children recently, which naturally translates into an increasingly early diagnosis.

Regarding treatment options, and since this work concerns clinical practice before the approval of any drug for the specific treatment of POMS, of a total of 30 patients, 28 initiated DMDs (one refused the medical proposal and, in another case, it was the option of the clinical team to postpone the start of any therapeutic intervention). Treatment of pediatric MS carries significant challenges due to insufficient evidence, particularly before the publication of studies conducted in pediatric populations, and this point has been included in discussions with the children and their caregivers. The first choice in most cases was interferon beta (36.7\%) or glatiramer acetate $(23.3 \%)$, in accordance with what is found in the literature..$^{5,9,10,21}$ Even so, in the last few years, there have been some cases in which oral treatment options were also discussed by the medical team at the time of diagnosis, but families often ended up making their decisions based only on the safety data associated with drugs due to concerns about the short time on the market of the oral treatments and the lack of knowledge of possible long-term adverse effects in children.

During the follow-up (mean $4.1 \pm 2.5$ years), 19 patients $(67.8 \%)$ had to change their treatment and the most common reason for discontinuation was disease worsening. After the classic first-line injectable drugs, natalizumab was the main choice, but it is of note that $20 \%$ of our patients, presenting a breakthrough disease, started their treatment with this monoclonal antibody. This was due to the aggressiveness of the disease, particularly in imaging terms, as is common in the pediatric population, which usually has quite a significant lesion load. ${ }^{22}$

Natalizumab and interferon-beta were discontinued due to personal choice in $33.3 \%$ and $18 \%$ of the cases exposed, respectively. In the case of natalizumab, this was due to positive serology for John Cunningham Virus after 2 years of treatment. Although these children had not been treated previously with any immunosuppressant, physicians decided to discontinue the use of natalizumab, fearing the main treatment-associated com- plication - progressive multifocal leukoencephalopathy. After natalizumab withdrawal, most patients started on oral fingolimod. Regarding interferon-beta, patients complained that they did not tolerate an injectable treatment, a common problem and concern in a young population. Local side effects were always considered worse than the flu-like syndrome associated with the use of interferons. One patient was treated with cyclophosphamide $800 \mathrm{mg} / \mathrm{m}^{2}$ for 12 months, as an induction treatment, due to a severe MRI lesion load presented at diagnosis, before natalizumab was available. The disease was controlled and treatment was followed by interferon beta- la for safety reasons. This treatment approach had been previously reported in the literature. ${ }^{23}$

The mean relapse number was $2.2 \pm 1.4$ during a mean time of follow-up of $4.1 \pm 2.5$ years. The majority of relapses involved the optic nerve $(32.3 \%)$ or spinal cord $(40.0 \%)$, similar to what was observed in the initial manifestation, but the involvement of the brainstem increased to $18.5 \%$ of the cases. Treatment of relapses was usually with methylprednisolone, but in $18.5 \%$ of the cases no treatment was administered, particularly in relapses with mild symptoms or without immediate medical evaluation. Progression of the disease, as measured by the difference between the first and last mean EDSS scores, was minimal and, despite a relatively short follow-up time, this supports the notion that progression in POMS is less significant than in adults.

This study has some limitations due to its retrospective and unicentric nature. Furthermore, the relatively small number of included patients does not allow a robust association analysis for the different variables to be performed. Nevertheless, it was the first to describe in detail the characteristics of such a specific cohort of MS patients in our region. It has also laid the foundation for a prospective registry that is being set up at our center and that is expected to be generalized to the whole country.

\section{Conclusion}

After the publication of the results of the PARADIGMS study, which led to the formal approval of the use of fingolimod to treat POMS, our approach to the disease changed. We began to inform patients and their families of the existence of a formally indicated treatment for this clinical condition, and this is reflected in the therapies currently prescribed in new diagnoses of POMS. The study we have presented provides a detailed analysis of the characteristics of the po- 
pulation with POMS that we diagnosed and followed at our center before this moment of change. In a few years' time, we would like to repeat this same protocol to search for any differences that may (or may not) be identified in relation to this very specific population of patients with MS.

\section{Responsabilidades Éticas}

Conflitos de Interesse: Os autores declaram a inexistência de conflitos de interesse na realização do presente trabalho.

Fontes de Financiamento: Não existiram fontes externas de financiamento para a realização deste artigo.

Confidencialidade dos Dados: Os autores declaram ter seguido os protocolos da sua instituição acerca da publicação dos dados de doentes.

Proteção de Pessoas e Animais: Os autores declaram que os procedimentos seguidos estavam de acordo com os regulamentos estabelecidos pelos responsáveis da Comissão de Investigação Clínica e Ética e de acordo com a Declaração de Helsínquia da Associação Médica Mundial.

Proveniência e Revisão por Pares: Não comissionado; revisão externa por pares.

\section{Ethical Disclosures}

Conflicts of interest: The authors have no conflicts of interest to declare.

Financing Support: This work has not received any contribution, grant or scholarship

Confidentiality of Data: The authors declare that they have followed the protocols of their work center on the publication of data from patients.

Protection of Human and Animal Subjects: The authors declare that the procedures followed were in accordance with the regulations of the relevant clinical research ethics committee and with those of the Code of Ethics of the World Medical Association (Declaration of Helsinki).

Provenance and Peer Review: Not commissioned; externally peer reviewed.

\section{References / Referências}

1. Alroughani R, Boyko A. Pediatric multiple sclerosis: A review. BMC Neurol. 2018;18:4-11. doi: 10.1186/s12883-018-1026-3.

2. Lee JY, Chitnis T. Pediatric Multiple Sclerosis Clinical Features and Course of Pediatric MS. Semin Neurol. 2016;36:148-53. doi: 10.1055/s-0036-1579738.

3. Chitnis T, Glanz B, Jaffin S, Healy B. Demographics of pediatric-onset multiple sclerosis in an MS center population from the Northeastern United States. Mult Scler. 2009;15:627-31. doi: 10.1177/1352458508101933.

4. Kamm CP, Uitdehaag BM, Polman CH. Multiple sclerosis: Current knowledge and future outlook. Eur Neurol. 2014;72:132-41. doi: 10.1159/000360528.

5. Correia AS, Augusto L, Meireles J, Pinto J, Sousa AP. Pediatric Multiple Sclerosis in Portugal: A Multicentre Study. Acta Med Port. 2016;29:425. doi: 10.20344/amp.6346.

6. Krupp LB, Tardieu M, Amato MP, Banwell B, Chitnis T, Dale $\mathrm{RC}$, et al. International Pediatric Multiple Sclerosis Study Group criteria for pediatric multiple sclerosis and immunemediated central nervous system demyelinating disorders: revisions to the 2007 definitions. Mult Scler. 2013;19:1261 7. doi: $10.1177 / 1352458513484547$

7. Thompson AJ, Banwell BL, Barkhof F, Carroll WM, Coetzee
T, Comi G, Correale J, et al. Diagnosis of multiple sclerosis: 2017 revisions of the McDonald criteria. Lancet Neurol. 2018;17:162-73. doi: 10.1016/S1474-4422(17)30470-2.

8. Carroll WM. 2017 McDonald MS diagnostic criteria: Evidence-based revisions. Mult Scler. 2018;24:92-5. doi: 10.1177/1352458517751861.

9. Otallah S, Banwell B. Pediatric Multiple Sclerosis: an Update. Curr Neurol Neurosci Rep. 2018;18:76. doi: 10.1007/ s11910-018-0886-7.

10. Krysko KM, Graves J, Rensel M, et al. Use of newer disease-modifying therapies in pediatric multiple sclerosis in the US. Neurology. 2018;91: e1778-87. doi: 10.1212/ WNL.0000000000006471.

11. Chitnis T, Arnold DL, Banwell B, Bruck W, Ghezzi A, Giovannoni $G$, et al. Trial of Fingolimod versus Interferon Beta-1a in Pediatric Multiple Sclerosis. N Engl J Med. 2018;379:101727. doi: 10.1056/NEJMoa1800149.

12. Polman $\mathrm{CH}$, Reingold $\mathrm{SC}$, Banwell $\mathrm{B}$, Clanet $\mathrm{M}$, Cohen JA, Filippi $\mathrm{M}$, et al. Diagnostic criteria for multiple sclerosis: 2010 revisions to the McDonald criteria. Ann Neurol. 2011;69:292-302. doi: 10.1002/ana.22366.

13. Statistics Portugal (National Statistical Institute). Resident population by place of residence. [Accessed 25 March 2020] Available at: https://www.ine.pt/xportal/ xmain?xpid=INE\&xpgid=ine_indicadores\&indOcorrCod=0 $008273 \&$ contexto $=$ pi\&selTab $=$ tab0\&xlang $=e n$.

14. Nielsen NM, Munger KL, Koch-Henriksen N, Hougaard DM, Magyari $M$, Jorgensen $K T$, et al. Neonatal vitamin D status and risk of multiple sclerosis: a population-based casecontrol study. Neurology. 2017;88:44-51. doi: 10.1212/ WNL.0000000000003454.

15. Disanto G, Chaplin G, Morahan JM, Giovannoni G, Hypponen $E$, Ebers $G C$, et al. Month of birth, vitamin $D$ and risk of immune-mediated disease: a case control study. BMC Med. 2012;10:69. doi: 10.1186/1741-7015-10-69

16. Yeshokumar AK, Narula S, Banwell B. Pediatric multiple sclerosis. Curr Opin Neurol. 2017;30:216-21. doi: 10.1097/ WCO.0000000000000452.

17. Cabrera SM, Bright GM, Lee PA. Age of thelarche and menarche in contemporary US females: a cross-sectional. J Pediatr Endocrinol Metab. 2014;27:47-51. doi: 10.1515/ jpem-2013-0286.

18. Guan $Y$, Jakimovski $D$, Ramanathan $M$, Weinstock-Guttman B, Zivadinov R. The role of Epstein-Barr virus in multiple sclerosis: from molecular pathophysiology to in vivo imaging. Neural Regen Res. 2019;14:373-86. doi: 10.4103/16735374.245462.

19. Langer-Gould A, Wu J, Lucas R, Smith J, Gonzales E, Amezcua $L$, et al. Epstein-Barr virus, cytomegalovirus, and multiple sclerosis susceptibility: a multiethnic study. Neurology. 2017:89:1330-7. doi: 10.1212/WNL.0000000000004412.

20. Motl RW, Sandroff BM. Benefits of exercise training in multiple sclerosis. Curr Neurol Neurosci Rep. 2015;15:62. doi: 10.1038/nrneurol.2012.136.

21. Chitnis T, Ghezzi A, Bajer-Kornek B, Boyko A, Giovannoni G, Pohl D. Pediatric multiple sclerosis: escalation and emerging treatments. Neurology. 2016;87:S103-109. doi: 10.1212/WNL.0000000000002884.

22. Waldman A, Ghezzi A, Bar-Or A, Mikaeloff $Y$, Tardieu M, Banwell B. Multiple sclerosis in children: an update in clinical diagnosis, therapeutic strategies, and research. Lancet Neurol. 2014;13:936-48. doi: 10.1016/S14744422(14)70093-6.

23. Makhani N, Gorman MP, Branson HM, Stazzone L, Banwell BL, Chitnis T. Cyclophosphamide therapy in pediatric multiple sclerosis. Neurology. 2009;72:2076-82. doi: 10.1212/ WNL.0b013e3181a8164c. 